\title{
Variety of Purpose in James Hogg's Manuscript of The Three Perils of Man
}

\section{Gillian Hughes}

This edition of Hogg's Border Romance The Three Perils of Man is the first to be informed by an awareness of Hogg's manuscript, which until recently was generally believed not to have survived, in the Fales Library of New York University. It had been assumed that, in line with common practice early in the nineteenth century, Hogg's manuscript would probably have been destroyed after its primary function as copy for the printers of the first edition had been fulfilled. ${ }^{1}$ The Fales Library is named for an important benefactor, Mr de Coursey Fales, a wealthy collector of rare editions and literary manuscripts who believed himself to be a collateral descendant of SirWalter Scott through the Haliburton family and whose collection was consequently rich in Scott materials. At some point Mr Fales also acquired this substantial manuscript of Scott's friend and fellow-Borderer James Hogg, and in 1963 it passed with other donations to the library of New York University. Its previous provenance is unknown.

The survival of so many manuscripts of novels by Sir Walter Scott is exceptional, and almost certainly motivated by the author's legal caution, as a proof of his creation of the anonymously-published Waverley Novels. As Scott's printers worked from a transcription in order to preserve his anonymity, it would be essential to retain his autograph manuscript as indisputable evidence of his authorship should that be challenged in future. ${ }^{2}$ A similar caution may once have preserved Hogg's manuscript for the anonymously-published The Private Memoirs and Confessions of a fustified Sinner, now missing but apparently owned by his descendants up to the 1890s. ${ }^{3}$ Others of Hogg's surviving prose manuscripts were created and retained for a variety of different purposes, which may usefully be outlined before looking at the specific case of his manuscript of The Three Perils of Man: since the name of James Hogg was inscribed on the title-pages of the three-volume first edition of 1822, the nature and status of this manuscript are likely to be rather different from those of a Waverley Novel manuscript. 


\section{Variety Among Hogg's Literary Manuscripts}

In the earliest days of his purely local fame as a writer, Hogg's work probably circulated primarily in manuscript: one of the motives Hogg gave Scott in his letter of 24 December [1803] for wishing to publish a volume of his poetry was 'being everlastingly plagued with writing copies and promising scores which I never meant to perform.. ${ }^{4}$ In later life, of course, Hogg produced manuscript copies, often signed and dated, of shorter poems as autographs or tokens of remembrance for his admirers, and as one would expect many of these presentation copies were treasured by the recipients and have accordingly survived to the present day. ${ }^{5}$ The manuscripts Hogg produced in his earliest years were not such gifts from an established writer to his enthusiastic readers, but the primary method of circulating his work locally by an amateur who was far from confident that it would achieve a wider circulation in print. In his letter Hogg is essentially trying to persuade Scott that his work is now so popular as to justify being printed. Through his earliest manuscripts Hogg established a limited readership and simultaneously built up a body of work that he hoped would form the basis of subsequent publications, either as magazine contributions or in volume form. Few of Hogg's early manuscripts have survived, the circumstances of his life as a shepherd and tenant-farmer who changed his address every year or two hardly favouring the preservation of papers in bulk. (A very high proportion of Hogg's surviving manuscripts were created subsequent to his marriage in 1820 and permanent settlement in Yarrow valley.) The earliest of his longer surviving prose manuscripts, those of his accounts of his Highland Journeys of 1802 and 1803, confirm these observations in that they are in the form of a series of numbered notebooks. Notebooks would be more durable than a series of loose sheets of paper, but could not so easily be divided among the different hands employed in a printing house: Hogg may well have expected to retain his fair-copy manuscript and transcribe all or part of the text subsequently for publication. In this case some of his account of the 1802 journey was promptly published as letters addressed to Scott in the Scots Magazine, but his account of the 1803 journey first appeared in print only in 1888, more than fifty years after the death of the author. ${ }^{6}$

After the outstanding success of The Queen's Wake early in 1813 Hogg probably assumed that his work would pass more swiftly and easily into print. He persuaded George Goldie, for example, to print six copies of his drama The Hunting of Badlewe for circulation among his literary advisors for their comment and suggestions for the work's improvement 
before publication, thus passing the labour of copying from his own right hand into those of the printer's workmen. ${ }^{7}$ These six copies, in other words, essentially substituted for an earlier circulation of his work in manuscript form. Hogg's dislike of the manual business of copying is clear. It could not have been easy to persuade the young publisher of that unexpected success The Queen's Wake to commit himself to the substantial cost of setting up his play in types only to produce a small number of copies that could much more easily and cheaply have been produced by transcription. Hogg's comments on the business of copying in later life confirm this impression. When he finally agreed to eliminate his 'ancient stile' from the component poems of $A$ Queer Book on 15 March 1831 it seems likely that Hogg passed the task of doing so over to his nephew Robert Hogg and his publisher at least partly because of his dislike of the boring work of transcribing them all:

I cannot correct the sheets for it would take me to write them all over agan $[s i c]$ but I beg to see the corrected copies before they are thrown finally off perhaps there may be a few favourite terms that I cannot part with. (Letters, II, 433)

In this case, a whole book was in question, but even in the case of shorter items to be contributed to an annual, Hogg's aversion to copying was much the same. Writing to Allan Cunningham, editor of The Anniversary, on 18 October 1829, Hogg declared:

Every body blames me for not writing my pieces twice over but it is as sure as I am writing you this letter that I take about double the time to copy an article that I do to write it exclusive of the terrible bore that it is. (Letters, II, 355)

Peter Garside has accounted for the preponderance of draft copies among the manuscripts of the Alexander Turnbull Library in Wellington, New Zealand (an accretion clearly made by Hogg himself and then inherited by his descendants) by supposing that they represent 'insurance against the loss or non-return of the submitted "top copy" of the work sent to a publisher. ${ }^{8}$ In other words, Hogg kept his rough draft of a poem or story as his personal copy rather than go to the trouble of making two fair copies of it, and he did this even for magazine contributions of a page or two, such as 'The First Sermon', subsequently published in Blackwood's Edinburgh Magazine, 27 ( June 1830), 879-80. Somewhat disingenuously, Hogg could therefore impress upon a potential publisher or magazine editor the uniqueness of the manuscript entrusted to his care when urging that it should be carefully returned to him if not used, and simultaneously have to hand a means of recreating the fair-copy manuscript with little 
more than the trouble of making a fresh transcription. ${ }^{9}$

In describing the Alexander Turnbull Library manuscripts, Garside carefully distinguishes them from Hogg's manuscripts among the papers of the Blackwood publishing firm in the National Library of Scotland, which 'consist of author's fair copies submitted by Hogg for publication.' ${ }^{10}$ These often show evidence of their use as printer's copy in the form of ink-stains or Blackwood's instructions to the printer of his magazine: the manuscript of 'Ane Rychte Gude and Preytious Ballande' among the Blackwood Papers (NLS, MS 4805, fols 3-7), for instance, bears signs of printer's thumb marks on fol. 3 and an instruction to the printer 'Bourgeois across the page' with William Blackwood's initials at the top of the first page. ${ }^{11}$

A third type of literary manuscript might best be termed an alternative version of a work to that appearing in print. Hogg showed that he possessed such a concept when writing of editorial interference to Allan Cunningham that 'He may spoil it in my estimation but I care not for that I can make it to please myself afterwards. ${ }^{12}$ There are a number of prose works for which two rather different fair-copy manuscripts have survived, the best-known case perhaps being Hogg's recollections of his long friendship with Sir Walter Scott. As Douglas Mack has explained, Hogg first wrote down his reminiscences of Scott for use by his young friend and publisherJohn Macrone in his projected Scott biography and this fair-copy manuscript, posted to Macrone in London in March 1833, survives in the Alexander Turnbull Library in New Zealand, as James Hogg Papers (Item 1). MS-Papers-0042-01. Under pressure exerted by Scott's son-in-law and official biographer, John Gibson Lockhart, Hogg withdrew his contribution to Macrone's biography, but later wrote out his extended reminiscences in a different order for publication in America, and this second fair-copy manuscript survives in the Pierpont Morgan Library, New York. The first manuscript affects to give Hogg's reminiscences as his spontaneous remarks written down by Macrone, and Hogg chose to present them rather differently when envisaged as a self-contained work published in his own name. Douglas Mack remarks, 'The circumstances in which the second version was published were entirely different from the circumstances of publication that had been envisaged for the first version; and as a result the second version is organised along very different lines'. Jill Rubenstein accordingly prints both versions together for the Stirling/South Carolina Edition under the title Anecdotes of Scott. ${ }^{13}$ There are a number of such double versions among Hogg's periodical contributions, such as, for instance, of his short tale 'Strange Letter of a Lunatic'. A surviving fair-copy manuscript represents the tale as submitted unsuccessfully to Blackwood's Edinburgh 
Magazine and there is also the rather different version eventually published in Fraser's Magazine, which must have been based on a fresh fair-copy manuscript. In such cases Hogg's first-written manuscript survives as a fair copy, without signs of having been systematically worked over by him after its return: rather than revising his existing manuscript and then transcribing the result, Hogg presumably set his old manuscript aside when creating the new version. ${ }^{14}$

Sometimes, therefore, piecemeal revision could disturb Hogg's necessary re-absorption in the creative process, and his new manuscript versions of a work were fresh compositions rather than revised copies. Hogg's creativity was not always impeded by the process of revising an existing text to create a new version of a work, however. On more than one occasion he provided printer's copy for a new version of a previously-published work by marking up a copy of the earlier printed text, perhaps also providing additional copy in manuscript. The fifth or subscription edition of The Queen's Wake of 1819 ('his carefully revised and polished final version'), for instance, has been published within the Stirling/South Carolina Edition as well as the first edition of 1813 ('Hogg's edgy and challenging original version'). In this instance, Hogg when working towards the 1819 version 'marked his revisions on a set of the sheets that had been printed for the third edition of 1814', these surviving as NLS, MS 20,440. ${ }^{15}$

Another alternative open to Hogg, once he had become wellestablished as a professional literary man, was to use the services of an amanuensis, who would transcribe a fair-copy manuscript from the author's corrected and revised draft. Hogg's uncertain financial position did not allow him to employ a paid copyist, but there are indications in his correspondence that young friends with literary aspirations were sometimes prepared to assist him in this way. Offering Robert Cadell an article entitled 'The History of Tom M,Fribble' in his letter of 1 March 1822, for example, Hogg stated that it was the work of 'a Mr. William Clerk a teacher here who copies a good many things for me'. In a letter to William Blackwood of 7 October 1820, discussing his progress in preparing copy for the printing of the second series of The facobite Relics, Hogg also described his brother William's eldest son, Robert Hogg, as 'my nephew who transcribes for me'. Charles Marshall, who taught the Mount Benger side-school in Yarrow parish in the final years of Hogg's life and was boarded in Hogg's family, describes his duties as including those of 'amanuensis and copying clerk' to Hogg. ${ }^{16}$

On other occasions it would appear that Hogg adjusted and patched an existing manuscript for a new publishing context, and length may well have been an important factor in deciding to do this. It would obviously 
be much more laborious to create a separate manuscript version of a book-length work than of a periodical contribution. Although Hogg did this in the case of his reminiscences of Scott, even the second extended version is unusually short as a separate volume publication, taking up less than 40 pages in the Stirling/South Carolina Edition..${ }^{17}$ By contrast, the five component fictions of Tales of the Wars of Montrose occupy 222 pages in the same format, the tales ranging in length from less than 16 pages for 'Julia M'Kenzie' to 98 pages for 'Some Remarkable Passages in the Life of an Edinburgh Baillie'. Fair-copy manuscripts survive for all five tales, bearing printer's marks corresponding to the printed volumes of the first edition, though it is not clear by whom or for what purpose they were preserved after printing had been completed. In the case of 'Julia M'Kenzie' there were once two different manuscripts, one representing the version of this tale included in Tales of the Wars of Montrose and another (of which a fragment only survives) representing the earlier version published under the title of 'A Horrible Instance of the Effects of Clanship' in Blackwood's Edinburgh Magazine, 28 (October 1830), 680-87. In the case of this relatively short prose work, Hogg may have preferred to create a new manuscript rather than revise the printed version in the magazine. For several of the longer tales, however, it seems likely that Hogg revised the original manuscripts he had created when the tales were written for an earlier projected collection of Lives of Eminent Men. Hogg's letters provide evidence, for example, that he had finished writing 'Some Remarkable Passages in the Life of an Edinburgh Baillie' on 3 March 1826, yet the initial leaf of paper of the surviving manuscript bears a watermark date of 1829 . The existence of two more types of paper in the manuscript suggests that the final manuscript used as printer's copy for Tales of the Wars of Montrose is a combination of leaves from Hogg's previous manuscript together with others containing passages revised between then and the date of publication. The manuscript of 'The Adventures of Colonel Peter Aston' also contains paper watermarked 1829, made subsequently to the date when Hogg stated that he had finished writing his tale, as well as a paper watermarked 1827. A deleted end-dating of ' $\mathrm{Jan}^{\mathrm{r}} 7^{\text {th }}$ 1825 ' suggests that when transcribing the final portion of his previous manuscript to incorporate the subsequent revisions marked upon it, Hogg had inadvertently copied the original end-date. ${ }^{18}$ In order to avoid the labour of writing out an entirely new manuscript copy of the longer tales in the collection, Hogg seems likely to have worked with the preceding manuscript, making fresh copies of only those portions where his revisions were extensive.

Several of Hogg's existing manuscripts appear to have been sent in 
to his publisher in instalments. Hogg's manuscript for The Brownie of Bodsbeck, covering most of the first twelve chapters of the total seventeen of the first edition of 1818, as Douglas Mack has explained, 'falls into three distinct sections, each of which has its own separate sequence of pagination in Hogg's hand', partly at least as a result of Hogg sending his manuscript to William Blackwood in batches. ${ }^{19}$ Having produced his original tale perhaps as early as 1813 , Hogg then felt obliged to revise it after the publication of Scott's Old Mortality, eliminating his own use of Balfour of Burley as a principal character. Blackwood appears to have read an earlier manuscript of Hogg's tale, which Hogg then revised and in part transcribed for publication in $1818 .{ }^{20}$ Hogg's manuscript of The Three Perils of Man also divides into a number of sections, each of which may be examined in the light of the variety of Hogg's practices outlined above.

\section{Description of the Surviving Manuscript of The Three Perils of Man}

The Fales manuscript of The Three Perils of Man is easily the longest of Hogg's surviving prose manuscripts, comprising more than two hundred leaves of paper paginated in sequence with the final page number $445 .{ }^{21}$ It is the only known survivor of the manuscripts that Hogg must have produced for his three long fictions of the early 1820 s, being followed by the companion The Three Perils of Woman and The Private Memoirs and Confessions of a Justified Sinner. All three works were published by the London firm of Longmans, whose letter-books provide only sparse indications of the firm's dealings with Hogg by comparison to the richness of the Blackwood and Murray archives in the National Library of Scotland. Hogg's correspondence and the manuscript together contain a good deal of information about the genesis of his Border Romance, but knowledge and understanding of its creation are still far from comprehensive.

The surviving manuscript is incomplete. There is one major gap in the pagination sequence (p. 14 is followed by p. 45), there are a number of missing leaves (pp. 59/60, 301/302, 344/345, and 360/361), and several others which have been divided and the top and/or bottom portion of the leaf subsequently lost (pp. 311/312, 330/331, 334/335, 342/343, $[372 \mathrm{~A}] / 373,374 / 375,380 / 381,428 / 429$, and 434/435). The manuscript has also suffered over the years from a great deal of wear and tear: besides the missing leaves and portions of leaves the paper has been abraded in places and torn, once conjugate leaves have been separated, and the final pair of conjugate leaves in particular survives only in a very scrappy state with the 
blank verso of the last leaf in an extremely dirty condition. Nevertheless, a manuscript exists for the greater part of the text of Hogg's three-volume Border Romance The Three Perils of Man of 1822.

Various papers can be identified in the manuscript, although most of the leaves measure somewhere around $31 \times 19 \mathrm{~cm}$, with only slight variations in size until p. 376, from which point a much larger paper than that of the rest of the manuscript was used, the single leaves of which measure roughly $38 \times 23.7 \mathrm{~cm}$. The spread of the various papers in sections of the manuscript is as follows:

Watermark R COLLINS | 1810 and shield countermark-pp. [1]-14

Watermark 1814 and shield countermark-pp. 45-64, 78-146, 313-19, 332-37, 354-57

Watermark RADWAY | 1808 and round crowned shield countermark-pp. 65-76

Watermark HARRIS | 1818 and crowned shield countermarkpp. 147-58, 163-200

Watermark C | 1816 and crowned shield countermark-pp. 159-62

Watermark J RUMP | 1817 and crowned shield countermarkpp. 201-32, 338-53

Watermark SMITH | 1818 and crowned shield countermarkpp. 233-308, 311-12

Watermark 1817-pp. 309-10

Watermark SMITH \& ALLNUTT | 1814 and crowned shield countermark-pp. 320-31

Watermark C | 1817 without countermark-pp. 358-75

No watermark, larger paper-pp. 376-445

A watermark in a manuscript can provide a terminus a quo for the date it was written, but it is not particularly helpful here to have a range of dates from 1808 to 1818 that in itself severely qualifies the usual assumption that paper would be used within a year or two of the date of manufacture. While it is not possible to state firmly when Hogg first began work on The Three Perils of Man it seems extremely unlikely that he had begun to work on it before 1818, since his letter of 4 [July] 1818 to the publisher John Murray seems to imply that, immediately after the publication of The Brownie of Bodsbeck, Hogg had not yet decided what his next major work was to be: 'Write to me as soon as convenient and tell me how the Brownie is liked and if it is likely to sell and whether I should set about a new tale or a new poem for next year at the same time'. ${ }^{22}$ The first solid indication of Hogg at work on his Border Romance comes in the recollections of James Raine of a meeting of the antiquary Robert Surtees and himself with Hogg in Edinburgh in the summer of 1819. Hogg had 
then requested Surtees to draw up 'a rough map of Northumberland, assigning to each district its clan, and noting the situation of the principal castles and fortresses'. ${ }^{23}$ From this it seems likely that Hogg was then in the early stages of composition, although, interestingly, similar paper to that used for the first section of the novel manuscript was also used by Hogg for letter-writing in June and July 1818. Moreover Hogg's letter to Murray of 4 [July] 1818 intriguingly refers to the erection of a four-roomed stone-built cottage on his farm at Altrive as 'building a castle', suggesting that castles were then at the forefront of his mind. ${ }^{24}$ The pattern of different papers used in the sequence of the surviving manuscript suggests that it is not so much a single copy as one created from a mixture of texts that evolved in the course of the progress of the work towards publication, and this is confirmed by the presence of two different handwritings in the manuscript, by a change of name at a specific point for one of the principal characters, and by the presence or absence of printer's marks in different sections of the manuscript.

\section{The Opening Section of the Manuscript}

While the majority of the manuscript is written in Hogg's normal drafting hand, the writing of the first section, comprising pages [1]-14 and $45-64$, is in a different hand altogether. An individual's handwriting, of course, varies with age, function, state of health, and physical tiredness. Hogg sometimes wrote out and signed presentation copies of his work in a more florid version of his usual hand with elaborated ascenders and descenders to certain letters, while his early Highland Journey manuscripts are written with straight descenders and more rounded shapes than his familiar drafting hand. The style of the handwriting of this early section of the Fales manuscript is not so foreign to some of Hogg's less familiar handwriting for it to be possible to state definitively that it was not written by Hogg himself. Nevertheless, a comparison between this hand and that of Robert Hogg in a fair-copy manuscript of one of his own poems is instructive. 'Linlithgow Palace' (NLS, Deposit 380 ) is also concerned with the chivalric past. It is carefully written and signed with a flourish, and obviously great care was taken in producing this fair copy of a two-page poem, a deliberation which would probably be absent in the task of copying page after page of a novel. Nevertheless there are distinct similarities between Robert Hogg's handwriting here and that of the first section of the Fales manuscript. 'Linlithgow Palace' helpfully employs a few of the same words as the relevant section of James Hogg's tale, including 'noble', 'eyes', 'deeds', 'ladies', 'the fair', 'arms', 'rust', and 'daughter', and their appearance in Robert Hogg's 
poem resembles their appearance in the initial section of the Three Perils of Man manuscript. The resemblance between the two hands is even closer in the separate pinned-on and pasted-down slips added to the Fales manuscript embodying revisions to the text: presumably these short passages were written freshly and when the scribe was not tired from sitting long at his task. Both the slip pinned to page 2 and the pasted-on motto for Chapter V on p. 53 share one distinctive feature with the fair-copy manuscript of 'Linlithgow Palace', that frequently when a word ends with the letter ' $d$ ' the ascender slopes left and finishes in a curl. It seems highly probable that the surviving manuscript up to p. 64 is basically a transcript made by Robert Hogg at his uncle's request, in order to provide a fair copy from the rough draft of the opening of Hogg's Border Romance. Hogg does refer in his letter to George Boyd of 27June 1821 to 'the corrected copy in Rob't's hand', but ambiguously for this might refer to a manuscript in Robert's possession rather than to one that had been transcribed by him. ${ }^{25}$ Robert Hogg was certainly providing printer's copy for the second series of The Facobite Relics of Scotland in the autumn of 1820 , and his refusal at about that time to proceed from his four-year course of general study at the University of Edinburgh to a theology course with ordination in mind meant that he had time on his hands for literary work. He eventually found work as a corrector of the press in Edinburgh, initially with the Ballantyne firm. ${ }^{26}$

Various revisions were made to this section of the manuscript. Judy King and Graham Tulloch argue in their Introduction that the original title under the paste-down replacement was probably 'The Perilous Castle | [TEAR] Tale of <????y $>$ Chivalry', and go on to discuss in more detail the interplay between it, the perilous Castle of Douglas, and Scott's writings about this legend of chivalry, suggesting that the second plot concerning the perils of Aikwood Castle may not have been an important part of Hogg's original conception (see pp. xviii-xx). The initial leaf of the Fales manuscript has been badly damaged, obliterating part of the replacement title on the slip pasted over this, which however seems to read 'The | [TEAR] <erilous Castles> | [TEAR] perils of Man; | or | [TEAR] Women, and Witch<ery $>\uparrow$ craft $\downarrow \mid$ [TEAR] order Romance'. An endorsement to Hogg's letter to George Boyd of 5 May 1821 gives the title of the work then as 'The | Perilous Castles | or | War, Women \& | Witchery- $\mid$ A Border Romance', the original reading of the pastedown slip (Letters, II, 77). The final change in the title seems to have been made that autumn, under pressure from the printers who needed to know what the running-heads for the text should be, with Hogg still uncertain about what title would be best. In his letter to Scott of 16 November 1821 he explained: 
There is another thing has puzzled me a good deal namely the title of my work. A mere bagattelle you will say No matter the printer cannot go on without it at the top The Perilous castle was fairly condemned by Grieve Blackwood and all who saw it as a title that a lady would give. It at present stands thus "The three perils of Man. Or; War, Women and Witchcraft!!" 27

Peter Garside explains the vital importance of a novel appearing under the right title at this time:

In a period when large numbers of new novels were published anonymously, titles naturally played a crucial part in signalling the specific generic character of individual works. Even where authors were named on the title-page, or otherwise known, the general tendency in circulating library catalogues was to list by title [...]

Proximity to other titles with the same lead word could, therefore, either help or hinder a work's reputation. Garside goes on to provide as an example that a "combination of "Romance" with any one of a number of keywords, including [...] "Castle" [...] almost invariably points towards a Gothic novel in the essentially female tradition of Ann Radcliffe'. ${ }^{28}$ Hogg's literary advisors in objecting to a title including the words 'perilous' and 'castle(s)' as one 'that a lady would give' were probably, therefore, warning Hogg against this unhelpful classification as a Gothic novel by the potential reader or purchaser. At any rate, the running-heads of the first edition were 'The Three Perils' on the lefthand side of the page-opening, with 'of Man' on the right-hand side. Having changed his title in accordance with his friends' advice, Hogg then made a couple of related changes to this section of his manuscript to eliminate the phrase 'perilous Castle' describing the castle of Roxburgh, both in his usual drafting hand. An early instance of 'perilous castle' remained on p. 4, but on p. 53 he changed 'Perilous castle' to read 'seige and the perils of Roxburgh' and on p. 58 'this Perilous Castle' to 'this castle'. A further revision in Hogg's hand seems designed to reinforce the new title of the work, when Princess Margaret requests Douglas to attribute his possession of Lady Jane Howard not to 'a miracle or by the power of a magician', but to 'a miracle by witchcraft or by the power of a mighty magician' (p. 62).

There are also other changes made in this part of the manuscript in Hogg's usual hand, which in one instance irons out an inconsistency that must go back to the earliest stages of composition. When Charlie Scott of Yardbire makes his appearance in Chapter V to convey the disguised Lady Jane Howard and her page to Douglas's camp, he originally takes the page 'on his huge gray horse behind him': in the 
subsequent narrative, however, Charlie frequently speaks to and of his horse as 'Corbie' (raven), and Hogg has accordingly adjusted his colour here to black (p. 63). Hogg also inserted a word here and there to clarify meaning or improve the flow of a sentence, and sometimes substituted a strong expression for a weaker or more usual one. The mysterious old man of the first chapter, for instance, originally stated his visions to have 'harrowed up my soul', a cliché which Hogg changed to 'torn up the tendrils of my spirit by the roots' (p. 9). When the Scott chieftain wishes his son to hear the old man's promises of future glory he originally said that a man was not the worse for a beacon "nor a house', changed by Hogg to the much more apposite 'a bit hope set afore him' (p. 11).

The manuscript as written showed signs that it was prepared as printer's copy. The instruction ' + new line)' was written at the head of p. 7, and repeated at the start of the second chapter. One heavily revised passage describing how the story was taken down by the editor from an original manuscript of 'an old curate' and introducing the Scottish court was rewritten on a separate slip of paper for clarity and pinned to its place on p. 2. The generally light revisions in Hogg's usual drafting hand seem to represent a last touching-up before submission of the manuscript, while printer's marks of ' $73 \mathrm{D}$ ' on p. 45 and ' 97 Vol. I. E' on p. 61 agree with gatherings in the first volume of the first edition of 1822 and show that this section of the Fales manuscript was indeed used as printer's copy. This being the case, it is particularly striking that throughout this portion of the manuscript the character who is termed Sir Ringan Redhough of Mountcomyn in the published work is named Sir Walter Scott of Rankleburn.

In his Familiar Anecdotes of Sir Walter Scott Hogg related that the change had been made in response to a kindly-meant warning from Scott, who after seeing some of the proof-slips had expressed concern that Hogg might lose the patronage of the Duke of Buccleuch, the contemporary head of the Scott clan and Hogg's own landlord, by his somewhat downto-earth portrayal of the Duke's ancestor in his new novel. ${ }^{29}$ Hogg's correspondence sheds further light upon the matter. In his letter to Scott of 16 November $1821 \mathrm{Hogg}$, writing from his Yarrow home, states, 'The first three sheets of proof are in my hands'.$^{30}$ The work was printed in gatherings of twelve leaves, so Hogg would then have gatherings $\mathrm{A}-\mathrm{C}$, taking the text up to page 72 of the first volume, while in Edinburgh his printer, John Moir, would presumably be setting up a further portion of the text in types for future correction by the author. Hogg's letter promises to 'stop the press until we shall decide what is fit and proper to be done' about the naming of the chief of the Scott clan, and plausibly the 
disappearance of the printer's marks after the one marking the start of gathering $\mathrm{E}$ represents the point at which this order was implemented in Edinburgh. Presumably Hogg's manuscript for the novel would then have been returned to him, but for this early section of the text he would be able to mark the necessary alterations on the proof rather than having to produce a fresh manuscript copy or return the existing manuscript suitably marked up.

\section{The Middle Section of the Manuscript}

From page 65 the Fales manuscript is written in Hogg's usual and familiar drafting hand, the printer's marks are discontinued, and the chief of the Scott clan continues to be called Sir Walter Scott of Rankleburn rather than Sir Ringan Redhough of Mountcomyn. In other words, at this point there is a change from printer's copy to author's draft of one kind or another, and it is plain that the Fales manuscript is not a single draft of The Three Perils of Man but a composite copy that has been carefully preserved, presumably by Hogg himself who is by far the most likely person to have had a newly-redundant part of the printer's copy and also an earlier draft of the work in his possession. Hogg's letter to Scott of 16 November 1821 had expressed his dismay at the thought of being required to do much rewriting:

The alteration of the name and title throughout is a trifle; but then he is Warden of the marches; has all to do in that line, and acts a principal part throughout. While all the subordinate chieftains Gemelscleuch Howpasley Yardbire (the champion and hero of the tale) Dickie of Dryhope \&c \&c. are all characters likewise, so that the name of the warden can never be concealed under any title It is a puzzling concern for me. I do not know this day what to do But of this I am satisfied that I must either make the character of the Warden such a one as will bear me through at all events with his illustrous [sic] house, or alter the whole of my romance, and it is a hard pill to swallow to write three volumes over again, or rather write three new ones, especially when one stands so much in need of his moiety.

In fact, as King and Tulloch indicate in their Introduction (p. xxviii), Hogg seems to have handled most of the necessary changes in a minimal fashion, referring to the Scott clan as 'Scots' instead of 'Scotts' or by phrases such as 'these wild border moss-troopers' and often simply substituting 'Sir Ringan' for 'Sir Walter'. Even the slightly more substantial alterations they also outline could easily have been made as 
revisions marked up on an existing fair-copy manuscript, which would still have remained legible and unambiguous to the printer. Only three weeks later, on 10 December 1821, Hogg reported again to Scott, 'I have gone over my new work from the beginning and altered the name Sir Walter Scott to Sir Ringan Redhough and all the other Scotts I have called them merely by their places of residence as John of Howpasley \&c. except Charlie Scott of Yardbire'. ${ }^{31}$ It seems doubtful that Hogg had produced an entirely new transcript of his novel in the time available to him. If a large part of the continuation of the manuscript returned by John Moir was marked by Hogg with the necessary alterations and then returned to him in Edinburgh this would explain the shift to a draft copy at this point in a manuscript preserved by the author.

This section from p. 65 appears to represent an earlier stage of the composition process than the first section of the Fales manuscript and changes eventually into a third section, which, though also written in Hogg's usual drafting hand, gives the name of the Scott chieftain as Sir Ringan Redhough and bears printer's marks corresponding with the gatherings of the first edition and must therefore have been used as copy by John Moir's workmen. The point at which the middle section of the manuscript ends is difficult to fix precisely: the first printer's mark indicating a gathering in the printed text, '289 N Vol. II Ch. VII', occurs on p. 307 of the Fales manuscript, but this is preceded by circled ink numbers ' 2 ' on p. 305 and ' 3 ' earlier on p. 307 that also look like the printer's work though their significance is unclear. Page 299 of the Fales manuscript is clearly from the author's draft rather than the fair copy since there Bishop Boldone 'was always called Red-hough', a name which is inappropriate to the printed text where it denotes the head of the Scott clan and where the Bishop is accordingly 'always called Bloody-Sark'. ${ }^{32}$ The name 'Bloody-Sark' recurs in the first edition (II, 273), but at a point where the leaf for pp. 301/302 is missing in the manuscript. It is possible that the changeover from author's draft to fair copy occurred at this point, for although the gap in the text seems of the right extent to fill one leaf completely in Hogg's usual hand, there appears to have been some confusion in the pagination of the leaves that follow: the next three leaves seem to have been originally mispaginated 305, 303, 306, 307, 308, 308 before being corrected to give the appropriate sequence of 303-08. Perhaps at this point Hogg was trying to work between two pagination sequences, one belonging to the printer's copy for the preceding part of the novel and another belonging to the rough draft from which he was creating a new fair copy for the printer for the remainder of it.

The middle section of the Fales manuscript therefore is part of a draft 
of The Three Perils of Man preceding both the first section, used by John Moir as copy for printing the first few sheets of the novel, and the final one where Hogg had adopted the name of 'Sir Ringan Redhough' in the body of his text. What does it reveal about the development of the work?

Although Hogg's letter to William Blackwood of 16 November 1819 anticipated his Border Romance as being ready for publication, in two volumes, in the spring of 1820 , it is clear that considerable delays occurred, partly because of the disruption to Hogg's time and habits caused by his marriage in April 1820. On 20 August 1820 Hogg confessed, 'I have been so much engaged in other matters that I have made no progress in my border Romance for about 3 months', while on 7 October he could still describe it as 'stationary I am sorry to say it for a long time'. ${ }^{33}$ During the following spring, however, Hogg was actively seeking a publisher, and on 5 May 1821 he wrote to George Boyd of the Edinburgh firm of Oliver and Boyd as follows:

I send you the two first vols of my Border Romance to read, but I have only sent a few sheets of the corrected copy that you might begin to print if you so pleased; the rest is the scroll copy which will however show you the model of the tale so far. The effect is principally in the last vol. in the final translation of Master Michael Scott by the devil; the taking of the castle of Roxburgh and the full denouement of the plot. The work is compleated but I must write nearly the half of the $3^{\mathrm{d}}$. vol over again before it can be shown (Letters, II, 75)

By this date then the work had extended to something like its published length, and the Aikwood plot had been fully developed. By 26 June Oliver and Boyd had rejected the work, partly at least because it was felt to be derivative of a Waverley Novel, but another objection may be gleaned from Hogg's defensive remark in his letter to the firm of 27 June 1821, 'Perhaps I should have told you that in the corrected copy in Rob'ts hand the friar's part was all taken out'. ${ }^{34}$ The most striking feature of this middle section of the surviving manuscript is that many substantial cuts have been made in the speeches of the Gospel Friar, presumably by Hogg as a first stage in producing the 'corrected copy' intended for publication. This middle section of manuscript thus almost certainly pre-dates the early summer of 1821 .

Hogg himself presumably kept the portion of his old manuscript with the deletions in 'the friar's part', partly no doubt so that when his top copy was handed over to a printer he could be ensured against the loss of his work should that clean manuscript be lost. He may, however, have had another reason for retaining it, revealed perhaps in the unusual way 
many of those deletions were marked. In general Hogg marks brief and routine deletions with one or several straight horizontal lines through the words to be excised, giving his new reading afterwards or above the line depending on whether a change was made instantly in drafting or after subsequent reflection. For more significant changes Hogg plainly sought to obliterate the original reading completely, obscuring it by a close pattern of loops so that a reader could only reconstruct his first thoughts with great difficulty, if at all, and there was no chance of a typesetter following his original rather than his corrected reading. There are examples of both customary kinds of deletion in this section of the manuscript. The two deletions in Hogg's description of the revelation of the disguised Lady Jane Howard's long hair are both made with multiple horizontal lines:

with the struggle the $<$ fair $>$ beautiful light locks had escaped from their confinement, and hung over $<$ it $>\uparrow$ her breast $\downarrow$ in waving ringlets. (p. 73)

By his first minor change Hogg substitutes one adjective for another and by the second he clarifies his meaning, but neither alteration signals a substantial change of mind. In the following example, however, where the deletion has been effected by close loops, Hogg has plainly decided to exercise a degree of self-censorship in deference to the sensibilities of his readership, and leave the threat to Lady Jane's person unspecified:

on that day at noon the lady of your heart would be exhibited $<$ naked on $>\uparrow$ in a state not to be named on $\downarrow$ a stage erected on the top of the Bush Law that faces the western tower, and is divided from it only by the moat; and there before your eyes, and in sight of both hosts, compelled to yield <her body to the conquest of his grooms $>\uparrow$ to that disgrace which barbarians only could have concieved; $\downarrow$ (pp. 98-99)

As Graham Tulloch has remarked, the nature of the threat in the revised version is still fairly obviously public exposure and rape, ${ }^{35}$ but Hogg has taken the decision that these are, in his own words, 'not to be named' and has indeed done his best to obliterate them.

In making cuts to the speeches of the Friar, Hogg has (as expected) marked minor changes by one or more horizontal lines through the words, but has made more substantial alterations with widely spaced slanting lines cutting almost vertically across several lines of text at once and leaving the excised portions entirely visible. In writing to William Blackwood as well as to George Boyd, Hogg made it clear that it was 'by advice' that he had 'taken out all the friar's part save some acts', 
and it seems likely that he thus left open the possibility of restoring it to what it had been should the work ever be reprinted ${ }^{36} \mathrm{Hogg}$ reclaimed and retained the final printer's copy of the last section of The Three Perils of Man, and therefore he could equally well have got and kept the final printer's copy for this part of the novel too. That he chose instead to retain an earlier draft of this section implies that the deleted 'friar's part' was vital to his overall conception of the work.

In echoing the language of the King James Bible for comic purposes in the Friar's speeches, Hogg plainly hoped to recapture an earlier success in the medium, when the 'Translation from an Ancient Chaldee Manuscript' had been in everyone's mouth and had secured the success of the newly-launched Blackwood's Edinburgh Magazine in October 1817. ${ }^{37}$ Hogg had written several follow-up articles, and was still making use of this language of scripture towards the end of his life in writing for annuals and for Fraser's Magazine. ${ }^{38}$ A number of the cuts made to the Friar's speeches simply shorten them, cutting out much of the elaboration of such biblical allusions, making them more succinct and (in the eyes of Boyd and Blackwood, if not Hogg's own eyes) less tedious. At the first illusory Aikwood feast, for instance, the Friar's extension to his reproaches against the steward Gourlay after the disappearance of the beef is cut:

he continued his anathemas on the steward. <"Wo be unto thee thou froward one! Thou hast taken the meat from the hungry, and the bread from him that was ready to perish. Either tell unto me where thou hast laid it-in what hidden corner it lieth concealed, or take unto thee a sword. For why should I smite thee? How then should I hold up my face to thy master? Why speakest thou not? Cursed be he that shutteth up his lips from the truth, that perverteth his ear that he may not hear, and closeth his eyes that he may not see. Verily such a man is not fit to breathe the blessed air, or to-">

"Blethering gouk!" cried Charlie (p. 235)

Charlie's comment, Hogg's literary advisors plainly feared, might well have been echoed by the reader.

Other deletions, however, effect a shift in the characterisation and role of the Friar, with which Hogg clearly had some problems. As a man of God and a medieval scientist with a popular reputation as a necromancer, the Friar obviously acts as an English counterpart to the Scottish Sir Michael Scott of Aikwood, as the man of God being opposed to the devil's man. The Friar, however, is clearly to be identified with Roger Bacon, whose reputation in popular legend was almost as 
doubtful as the Wizard's. Where the legendary Michael Scott splits the Eildon Hills and transports men instantly to distant places, Bacon was best known in legend for his creation of the speaking Brazen Head, which is supposed to have said at intervals 'Time is', 'Time was', and with 'Time's past' fell to pieces, while Bacon slept and his faithless assistant failed to alert him. Hogg may not have read Robert Greene's Honourable History of Friar Bacon and Friar Bungay (1594), but allusions to the story are common in literature he undoubtedly knew, from Pope's Dunciad and Butler's Hudibras to the first canto of Byron's Don Juan, which Hogg had cited in his previous prose fiction publication Winter Evening Tales (1820). ${ }^{39}$ How, then, was Hogg to distinguish between two figures who in popular legend both have an aura of uncanny and forbidden knowledge?

Nationality seems to have been one distinction, since in this fiction at least Hogg apparently envisaged the Scots as more superstitious than the English. At the novel's conclusion when the Scottish court are tempted to flee from the approaching laird of Peatstacknowe, whom they suppose to be a devil, they are opposed by 'Sir Charles' English lady, whose education had taught her to despise the superstitions so prevalent in Scotland' (III, 409). Obviously, the Wizard's contempt for religion and the Friar's biblical language mark another. A third perhaps is that while the Wizard is always solemn in pursuit of the sublime, the Friar (like his creator) is somewhat amused by pretensions to sublimity-he performs his part in the magical contest with the Master 'with a waggish air', for instance (p. 243). He can also acknowledge and admit to human faults and failings, and this is particularly obvious in Hogg's manuscript where the Friar was more inclined to physical violence before Hogg made his deletions. When Gourlay, entering the dungeon to abstract Delany, is defeated by the prowess of Charlie Scott, for instance, the Friar first advocates killing him, then decides to kick him, before calming down and deciding that the right thing is to tie him up as a prisoner.

$<$ "Did I not say unto thee that he was a man of belial? and better were it for us, and better for our kinsmen, better for our master, and better for all the children of men, if he were made as the bones among which he is fallen down. [...] Shame were it for one to wound or put his sword into the body of a fallen man nevertheless I will give thee one kick with the foot that thou may'st learn to humble thyself in the land of the living." $>$

The rage of the seneschal when he saw himself robbed of the keys of the castle is not to be described: he cursed and <raged $>$ $\uparrow$ raved $\downarrow$ in such a manner, that even after the friar had both doors fairly open, Charlie durst not move from off him or let him go for 
fear of some deadly scaith. [...] "He'll no settle till he be pierced" 个said Gibbie $\downarrow<$ Nay my brethren," said the friar "I only spoke as one of the foolish men speaketh; let us not do this thing, and sin against the most high. But lo I will bring unto thee cords as the cords of a man, and we will bind him as with fetters and he shall be bound."> (p. 218)

Hogg's deletions increase the superficial dignity of the Friar, who as a man of God should not advocate violence, but remove that tendency to reflect effectively upon his own faulty impulses that is so lamentably lacking in the Master of Aikwood.

Hogg effects a similar shift in his revisions to the scene where the poet, overhearing the Friar's religious conversation with Delany, becomes convinced that he intends to seduce her person and apprentice her to the black arts. Hogg's deletions increase the Friar's dignity by cutting down the number of double entendres (which he may also have felt on reflection would be unacceptable to the readership of the novel), even though they make the poet's jealousy rather less comprehensible. His original address to her includes:

Lo I < even $D$ will be unto thee a father and thou shalt be unto me as a daughter, <and I will exult my horn on high and put down the crooked serpent of iniquity within thee $>$

The poet's rage on hearing this is heightened by the Friar's subsequent promise that Delany will 'bring forth fruit abundantly', and culminates in an attack when he hears the Friar declare: 'Lo I will be always with you, and my arms shall be underneath and around you. $<$ When $>$ $\uparrow$ and when $\downarrow<y>\uparrow$ th $\downarrow$ ou art faint and weary I will hide thee in my bosom; <and when thou art naked I will cover thee>' (pp. 197-98). Hogg's work elsewhere refuses to divorce spiritual and earthly love, and here as so often Charlie's comment on the Friar's attraction to Delany seems just: 'I see there's nae man can help liking a bonny lass, but the better a good man likes ane, he'll be the mair sweer to do her ony skaith' (p. 196). It is the poet's folly to interpret his speeches into threats of seduction, physical or spiritual: the Friar with all his faults and want of dignity is a good man.

The other problem Hogg had with the Friar is in the revelation of his true identity as Roger Bacon, which at various points needs to be indicated to the reader but concealed from other characters. In this portion of the manuscript his true name is often openly mentioned by the other members of the embassy, who are plainly unaware of Friar Bacon's wider reputation as a necromancer until Tam Craik informs them that he has studied the black arts at Oxford and been disciplined 
for it, presumably by or at the instigation of the church (p. 194). These early mentions of his name are helpful to the reader in preparing the ground for the contest between the Friar and the Wizard to follow. The open naming of the Friar as Bacon is, however, somewhat inconsistent with his necessary maintenance of an incognito when brought in contact with that pillar of the church Abbot Lawrence at Melrose Abbey, as well as with his subsequent revelation of his identity to the Wizard in confidence on the grounds that he has been 'hunted from nation to nation, and from land to land' before finding shelter with the Scottish Borderers (p. 237). On a number of occasions in this section of the manuscript Hogg deleted 'Bacon', sometimes replacing it with 'the friar', before reaching the final solution arrived at in the published novel of never naming the Friar directly as Bacon but only hinting strongly at the identification to an alert reader. ${ }^{40}$

Other revisions in this section of the manuscript demonstrate Hogg tidying up the details of his plot and eliminating inconsistencies. Sir Walter Scott's lady, for instance, was originally named 'Margaret Douglas', consistent with her 'high spirit and proud unyielding temper' (p. 140), but less so with her urging her husband not to lend his support to Lord Douglas himself. Another original inconsistency at this point was that Gibbie Jordan was first stated to be present at the Warden's council that determined to send out an embassy to the Wizard, and was then called into the circle to be informed he is to go with them. The following deletion rectified the matter: 'There was none of those nominated for the mission present but Muckle Charlie Scott < and the laird of the Peatstacknowe>' (p. 141). Hogg also thought at first to hint that Charlie already admired the Lady Jane Howard when the embassy initially set out on their mission, for in discussing Delany's attractions he declared, 'I ken o ane that I wadna gie for a fauldfu' o' her but $\uparrow$ we $\downarrow$ maunna say nae mair about that' (p. 147). The hint was not followed up subsequently, the possibility of a marriage of Charlie and the lady being raised only after the death of her betrothed, Lord Musgrave, and purely as a result of the machinations of Mary Kirkmichael. Such an isolated clue might easily be overlooked by the reader, and even if not it sorts badly with Charlie's otherwise impressive humility and modest worldly ambition. Hogg wisely deleted it. The Friar originally gave the name of his comically warlike mule as 'Judas Maccabeus' (p. 177), but subsequently preferred the equally appropriate and better-known 'Goliah of Gath' so the earlier name had to be deleted. In the Friar's Tale,Jacques de la Veny is initially wounded in the fateful duel with the younger Friar 'in the loins, so that my sword found a passage through his body' (p. 265) whereas he tells a party of soldiers shortly afterwards 
that de la Veny's wound was 'under the fifth rib' (p. 267) until Hogg removed this inconsistency.

A few alterations in this section of the manuscript appear to suggest that Hogg was conforming to a convention then existing in Scottish novels, based on (or at least hugely reinforced by) the example of Sir Walter Scott, that while speeches might include colloquial and/or Scots expressions narrative should be much more formal. The monk Benjamin relates to Douglas how the page Colin visited him in search of writing materials 'which he could not otherwise <come at> $>$ procure $\downarrow$ ', and that his ghost subsequently beckoned the monk to 'keep <my distance $>$ $\uparrow$ away from his person $\downarrow$ and glided backward' (p. 133). Where Gibbie originally related his stories 'whiles to one, whiles another' this was deleted and more cumbersomely he then related them 'sometimes to one sometimes to another as he found them disposed to listen' (p. 144). Jock's 'wee housie' becomes a 'sheiling' (p. 280), and so on.

Other revisions show Hogg refining the details of his characterisation. The description of the Master of Aikwood's manner as being 'like <a mountebank's>' was deleted, and so was his opinion of a cannibal feast, '<what better or more wholesome beverige could be found?>' (pp. 259, 260). Charlie Scott's high opinion of the Friar in their pursuit by the Halls is emphasised, presumably as a guide to that of the reader, by the addition above the line of the statement that 'He's ane that there's something sterling about' and by his altered response to the Friar's advice, 'I hae heard waur advices frae mair < sensible $>\uparrow$ warlike $\downarrow$ men' (pp. 170,171). The selfish solitary greed of the Deil's Tam is emphasised by deleting the improbable detail that he has 'a wife of his ain' (p. 147), and where once he "cared not much about any thing provided he got plenty of drink and sport' these were altered to the more characteristic 'drink mischief breaking of heads and fat bacon' (p. 143). For the benefit of the cloth-eared reader who might fail to notice that the poet's speeches tend to drop into iambic pentameters, Hogg adds to the information that the poet's conversation was threaded on chance connections in his mind between one old rhyme and another a hint that 'his words chimed naturally into measure' (p. 190). Sir Michael Scott's demonic attendants were originally named 'Gib Gill and Grizel' before being more menacingly but no less alliteratively called 'Prig Prim and Pricker' (p. 207).

Finally, several details in this middle section of the Fales manuscript confirm that it does indeed predate the first section and the final one. Most obviously the portion set in Roxburgh (from the conclusion of the fourth to the ninth chapter) contains several descriptions of Roxburgh as 'the perilous castle' or even 'Perilous Castle', the phrase not having 
been deleted as it was in the first section of Hogg's manuscript that served as copy for the printer. ${ }^{41} \mathrm{~A}$ single reference to the other castle, where not a chivalric but a magical contest takes place, as 'Oakwood' rather than 'Aikwood' is of particular interest, in suggesting that Hogg deliberately substituted a Scots form of the usual name by which the peel tower in Ettrick valley was known in order to emphasise the contrast between the two castles. ${ }^{42}$

\section{The Closing Section of the Manuscript}

The closing section of the Fales Manuscript was plainly the last to be written, since in this the name of the head of the Scott clan is no longer Sir Walter Scott of Rankleburn but Sir Ringan Redhough of Mountcomyn, a change instigated as we have seen by Sir Walter Scott of Abbotsford and implemented by Hogg in late November and early December 1821. Although, as previously explained, it is hard to fix the precise point at which this section begins it seems certain that it must be after p. 299 and before p. 307, with the missing leaf containing pages 301-02 representing a likely point of transition. The final section of the manuscript thus begins somewhere towards the end of the nineteenth chapter (the penultimate chapter, VII, in volume 2 of the first edition) and then continues until the end of the story, marked by Hogg with a firm 'Finis' on p. 445. It comprises 'Tam Craik's Tale' and 'The Poet's Tale', the arrival of Dan Chisholm at Aikwood and the departure of the embassy, with the final resolution of the Roxburgh plot, and the death of Sir Michael Scott at Aikwood. Plainly this section of the manuscript was used as printer's copy for the first edition. It bears the following printer's marks corresponding mostly precisely, but occasionally approximately (presumably the result of changes by Hogg in proof), with the start of the gatherings of the published text:
p. 307
289 N Vol. II Ch. VIII
p. 316
p. 327
Ch. 8 Vol 2. O 313
p. 335
337P
p. 359
Vol. III A 1
p. 369
49 C Ch. II
p. 377
73 D Vol. III C. II
p. 387
E 97 Ch. III
p. 393
G 145 Vol. 3 Ch 5
p. 398
169 H C. VI
p. 404
193 Vol. III I Ch. 7.
p. 409
217 K C VII
241 L VIII [Hogg's '25th' deleted] 


$\begin{array}{ll}\text { p. } 413 & 265 \text { vol. III M } \\ \text { p. } 417 & 289 \mathrm{~N} \\ \text { p. } 421 & 313 \mathrm{O} \\ \text { p. } 426 & 337 \mathrm{P} \mathrm{Ch} . \mathrm{X} \\ \text { p. } 430 & 361 \mathrm{Q} \\ \text { p. } 434 & 385 \mathrm{R} \\ \text { p. } 438 & 409 \mathrm{~S} \\ \text { p. } 442 & 433 \mathrm{~T}\end{array}$

Hogg also gives directions to the printer about the setting of specific portions of his text. For example, when the poet drunkenly recites verses from the song 'When the Kye Comes Hame' Hogg notes '(This verse and those that follow to be in half line)' (p. 342). It seems at least possible, though by no means certain, that this part of Hogg's manuscript was prepared in sections for the printer: the verso of the leaf containing p. 317 (dividing the two parts of 'Tam Craik's Tale') is blank. There is a blank half-page on p. 372 between the end of Chapter 22 and Chapter 23 (which begins on an unnumbered leaf, [372A]) in sharp distinction from Hogg's usual practice of filling his paper, even where as on p. 398 part of the motto to Chapter 27 is squeezed into the end of a page; Hogg's text also runs straight from p. 367 to p. 369, suggesting that he may have forgotten when he resumed his pagination sequence that he had concluded the previous section with p. 367 rather than p. 368.

There are clear indications in this section of Hogg's eliminating references to the Scott clan from an earlier draft. On p. 414, for instance, Hogg had written and then corrected 'Scotts' to 'Scots' by drawing a line through the second ' $t$ ', while on p. $335 \mathrm{Hogg}$ has failed to eliminate the Scott clan cry of 'A Bellandine' hallooed by Dan Chisholm when locating the Warden's embassy at Aikwood. In preparing this printer's copy, however, Hogg goes beyond a simple transcription to avoid Scott references, to revise and refine his work further. This section of manuscript demonstrates his continuing imaginative engagement with his creation in a number of different ways.

Firstly, Hogg eliminates close verbal repetition in several places. Tam describes his situation at his master's house, for instance, as providing opportunities for 'stolen meat, and <stolen $>\uparrow$ approaching $\downarrow$ pleasures' (p. 311). In another instance, Hogg decided to eliminate the word 'great' to describe the wizard because it was also used in the following speech to describe the devil: "said the <great> Master. "This great primate [...]"' (p. 389).

Phrases are also added to remind the reader of previous events in the story. At Bess Chisholm's wedding, for instance, Hogg first wrote that 'her wounds were not quite whole' but then expanded this to say 
that ' $<$ her $>\uparrow$ the $\downarrow$ wounds $\uparrow$ she recieved in the engagement with the marauders $\downarrow$ were not quite whole', a timely reminder of her earlier bravery in challenging the English thieves of her father's farmstock (p. 417). Similarly, when Charlie declares his want of faith in the fairness of the lottery held at Aikwood 'after what I heard the king of a' warlocks say' Hogg has added a reminder above the line of what the wizard did say, namely 'that the lot wad fa' in this way' (p. 376).

Some of Hogg's most interesting insertions, however, represent entirely new ideas or amplify existing ones in fresh ways, rather than simply act as memory aids for his reader. Dan Chisholm, just arrived at the castle of Aikwood, comments, 'It's a queer place this, an' as queer fock about it', newly emphasised by the addition of a fresh uncanny response squeezed in between this and the next line, "What's queer about it lad?" said a strange voice through the key hole whence it would not speak again' (p. 337). Addressed unexpectedly by a little girl as he instructs his troops, Charlie's downward glance is compared to that of a man who has 'dropt a curious gem $\uparrow$ or pin on the ground $\downarrow$ and cannot find it' (p. 434). The body of the witch who has had the devil as her bridegroom is not only 'strangled' but ' $\uparrow$ squeezed almost to a gelly and every bone broken as if it had been smashed on an anvil $\downarrow$ ' (p. 441). Old Pate Chisholm, aghast at the extravagant consumption of food in his house, is nevertheless eager to consume his share of the meal, Hogg adding as an afterthought, 'He however plied as good a knife and as good a horn spoon as any of them all' (p. 404). Hogg also clarifies the details of his plot in producing printer's copy. After explaining that Will Laidlaw does not recognise his sweetheart Bess Chisholm in man's attire, Hogg adds 'neither did she once suspect him' (p. 402) because of his disguise as a skin-dealer.

Just occasionally Hogg's creative engagement fails and in the work of revision he obscures or eliminates an apt or necessary detail. He had related of the Poet's conversation, for example, 'If one word spoken chanced to occur in any old rhyme or song that he knew, he went over the sentence to himself, though it had no farther connection with it, or resemblance to it, than merely that word' $(I, 315)$. Accordingly, the poet begins to sing disconnected portions of 'When the Kye Comes Hame' because Charlie Scott, in reproaching him mildly for his drunkenness, has provided a suitable trigger for it. 'Whisht, whisht, and ye sal tell your tale, or sing your sang which you like; and then you are free to take a collop or gie < ane $>\uparrow$ a collop wi' the best o' them $\downarrow<$ and to kiss a bonny lassie when the kye comes hame $>$ ' (p. 341). Unfortunately, in simplifying the passage Hogg has deleted the cue for the song.

By far the bulk of Hogg's corrections, however, work in the opposite 
direction, to reinforce and emphasise his original intentions. The anxious King Robert, for example, enquiring about the fate of his daughter originally referred to 'her' but more emotively in revision to 'our darling' (p. 422), while Douglas turns aside his challenge to fight by saying, 'The Douglas draws not but on his equals, and thou art $<$ no match for him> $>$ none of them $\downarrow$ ' (p. 425), a rephrasing which recalls not only the King's age and lameness but also his sacred state as consecrated monarch.

Finally, it is possible to detect an element of self-censorship in these final revisions. Hogg refines his language and makes it less colloquial for his readership, substituting, for instance, 'substance' for 'stuff' (p. 307), and 'choosing' for 'waling' (p. 331). He is also alert to tone down sexual innuendo here and there. The following revision, for example, shifts the proximity of Tam's body to that of Kelly in her bed and makes it less plain that he takes pleasure covertly in it:

and then she kindly <covered me with her own bedclothes $>\uparrow$ laid the uppermost coverlet over me for fear of my catching cold $\downarrow$, but I was by far too sound asleep to percieve it. She had to pull the $<$ clothes $>\uparrow$ covering $\downarrow$ from below me, in order that she might lay $<$ them $>\uparrow$ it $\downarrow$ above me, $<$ but $>$ for all that I did not $<$ think proper to $>$ awake $\uparrow$ which was a great pity $\downarrow$ but always as she made the greatest stir, I sniffed the louder. (p. 311)

Instead of their bodies lying next to one another, they are now separated by the majority of the bedclothes as Tam is specifically covered only by the 'uppermost coverlet'. Even so, in Hogg's revision he is relatively unaware of their closeness at the time and appears to regret it subsequently. A similar change is made to the expressions of the old wives who are deploring Tam's confinement to the stocks for fornication, which in the original was less maternal than in the revised version:

"Poor fallow! Some body may be the better o' him yet. < To be sure he's but a young practitioner, but they that learn young learn fair. $>\uparrow W h a t$ wad the mother that bore him say if she saw him standing in that guise? Surely she wad think the punishment far outwent the crime $\downarrow . "$ (p. 313)

By deleting the inapt proverb here and adding a reference to Tam's mother, the feeling that somebody may be the better of Tam is put into a fresh context and the taboo reference to the old women's sympathy as underpinned by sexuality is avoided.

Hogg may not have relished the work of writing out a large portion of The Three Perils of Man once again, but the conclusion of his Border 
Romance was undoubtedly enriched and tailored more precisely to his reader's needs and expectations by the accompanying re-engagement with the details of his story.

\section{Hogg's Manuscript in Process}

An author's manuscript is not the end of the creative processes involved in producing his work, which will generally continue to operate during the production process by means of the author's proof-corrections as well as the anticipated interpretation of and completion of his work for its public appearance by the printers. Sometimes, as in the case of several of Scott's novels, it is also reasonable to include part of the production of subsequent editions as well as of the first as part of this initial burst of creativity. ${ }^{43}$ In their Introduction to the present volume (pp. xxv-xxxii) King and Tulloch discuss the most significant changes between Hogg's manuscript and the first edition of The Three Perils of Man, and debate Hogg's level of involvement in the production process.

The comparison with Scott is also instructive in another respect. Scott's intense productivity allowed him to realise his dream of Abbotsford. The 1820s was also a decade of frenetic publishing for Hogg as he struggled against a sea of debt originating at the start of his nine-year lease of the large Mount Benger farm at Whitsunday 1821: he was never sufficiently prosperous to stock it well enough to turn a profit or able and inclined to give it adequate attention to ensure it was run efficiently and economically, and it ate up all his literary earnings faster than he could make them. ${ }^{44}$ In working under pressure on the manuscript of his Border Romance through its various stages, Hogg eliminated a number of inconsistencies in the plot, but he also inevitably overlooked one or two minor problems of this type as well. Scott was fortunate in the oversight of an eagle eye for such matters, that of the devoted James Ballantyne, who would raise queries and point them out to the author at the proof stage: Hogg was almost certainly alone. Some inconsistencies in close proximity to one another he did pick up, such as Gibbie Jordan's presence or absence at the Warden's council that decided upon sending out an embassy to Sir Michael Scott (see above). Others remained to be imperfectly dealt with, or simply overlooked altogether. One such problem is that of the King of Scotland's family. In the first section of his manuscript Hogg had originally written: 'Our worthy king had one daughter of exquisite beauty and accomplishments: < she was his only child $>$, the flower of all Scotland, and her name was Margaret' (p. 2). Hogg's deletion here removes the inconsistency involved in her disguising herself shortly afterwards as her brother, Prince Alexander 
Stuart. Nevertheless she remains the king's 'one daughter', up to the point where Douglas ponders on his future after her supposed death in the castle of Roxburgh and reflects that 'the king had more daughters, though none like his beloved and accomplished Margaret' (p. 395). Another inconsistency concerns the identity of the person in the devil's grip as the embassy departs from Aikwood in the form of a herd of cattle. They look back and see the devil as a figure of monstrous size standing on the topmost tower of the castle:

at the same time that they saw Satan stretching out his sceptre in his right hand, he held out Tam Craik by the nape of the neck in his left, while the poor fellow was seen sprawling and spurning the air over an unfathomed void.

Tam's fate is the result of his having signed a bond of blood with the devil in return for the promise of as much fat flesh as he could eat by day or by night for the first three years of his novitiate. His fate is then summarily dealt with by the narrator who reports that after feeding him for a certain time the devil wearied of 'such a voracious cur and twisted his neck about' (p. 390). Gibbie Jordan is also left behind, in feudal attendance on Master Michael Scott, by agreement rather than as a result of his having signed himself away to the devil. Yet Charlie, on seeing Gibbie again after his release from service by the wizard's death, recalls, 'the last time I saw that carl, the deil was haudding him by the cuff o' the neck out ower the topmost tower of the castle of Aikwood, and the poor laird was sprawling like a paddock in a gled's claws when fifty fathom frae the ground' (p. 439).

Through the various spaces, deletions, and additions of the Fales manuscript some of the processes whereby Hogg created it can be traced and also a little of his working methods. The provision of mottoes at the head of each chapter of this novel was perhaps made in imitation of Scott's Waverley Novels for a Border Romance operating to a certain extent at least in Scott's literary territory. Of Hogg's other long prose fiction publications of the 1820 s neither The Brownie of Bodsbeck nor The Three Perils of Woman employ them. (The Private Memoirs and Confessions of a fustified Sinner consists essentially of two long narratives rather than a succession of numbered chapters.) The manuscript suggests that Hogg had some difficulty in providing these mottoes to his own satisfaction: of the thirty-two chapters of the novel several appear to have had the mottoes added after the chapter had been written out, even in those sections which clearly do not represent Hogg's original draft. The mottoes for chapters 1, 5 and 32 are on paste-downs, for instance, and clearly represent second thoughts, while those for chapters $2,13,16$, 
and 21 are written in a darker ink than the chapters that follow them, suggesting that in writing Hogg left a gap and filled in the motto at another time-for Chapter 16 indeed the gap was rather larger than necessary for the motto. At the start of the sixth chapter Hogg had originally written 'Chapter VI' below the space for the motto as well as above, before deleting it. There are also repeated indications that Hogg sometimes added his punctuation after he had drafted a sentence, in that commas or semi-colons sometimes occur at the beginning of a line rather than immediately after the word they follow at the end of the preceding line. Hogg's careful, subsequent addition of these marks is surely a measure of his desire to guide the printer in applying a detailed system of punctuation to his work. ${ }^{45}$

Although printing and publication must have been generally envisaged by Hogg as the natural completion of his work, his manuscript of The Three Perils of Man suggests that the process occasionally acted as a constraint. In his letter of 16 November 1819, Hogg had described the work to William Blackwood as 'a romance in two volumes' ${ }^{46}$ and from this and other evidence King and Tulloch have argued in their Introduction (pp. xviii-xx) that the Aikwood plot may not have been an important feature of his original conception but was formed afterwards, partly to extend the work to the three-volume format favoured by contemporary publishers and the circulating libraries. It seems likely that Hogg then had problems containing this second narrative within that space, for anxiety about excessive length is vented in the narrator's various statements on his treatment of the suppositious earlier narrative of Isaac the curate:

It is now absolutely necessary to shorten the curates [TEAR] to prevent this work running to an inordinate size, and though two of his tales have been left out already, the great events that follow $<$ ed $>$ must also be related in an abbreviated stile although never mangled by indistinctness. (p. 409)

Most of these passed into the published volumes, but one particularly significant one did not: the narrator justifies his cutting out the chapter and a half Isaac the curate devotes to a description of the royal wedding 'in order that my matter may be brought to suit exactly the size of my last volume, which my publishers say ought not to exceed the size of the others. Or at all events not above twenty four pages' (p. 428). The third volume of The Three Perils of Man is 449 pages long, as opposed to 341 and 353 pages for the first and second volumes respectively, more than the single gathering of twelve leaves or twenty-four pages referred to in this passage. It is interesting to speculate that Hogg may well have 
been inclined to stretch his Border Romance into a fourth volume.

As an artefact reflecting several different stages of Hogg's creation of The Three Perils of Man rather than a fair copy of the entire work as printed for publication in 1822, the Fales manuscript cannot act as a substitute for that first edition since decisions taken at one time are not easily reconcilable with those taken at another by anyone other than the author himself. It may, however, act as a point of reference for a modern edition based on the first, as a corrective to some of the misreadings or misunderstandings of printer and publisher. Its primary value, however, is as a unique and fascinating object for study, containing much detail about Hogg's creative methods and the gradual development of the work-a glimpse into the mind of a great Scottish writer.

\section{Notes}

1 This essaybuilds on my earlier paper'Recovering Hogg's Personal Manuscript for The Three Perils of Man', Studies in Hogg and his World, 13 (2002), 104-26.

I am grateful to the Beinecke Rare Book and Manuscript Library of Yale University for awarding me the Frederick A. and Marion S. Pottle Visiting Research fellowship during 2001/2002, which not only enabled me to work on the library's own collections of James Hogg letters and manuscripts but to visit other New England libraries with Hogg material during my stay in New Haven. I would also like to express my gratitude to the Bibliographical Society for its award of a research grant enabling me to return to the Fales Library of New York University for further research. I am grateful to the Fales Library for permission to quote from Hogg's manuscript for The Three Perils of Man in this essay, and to the Trustees of the National Library of Scotland for permission to cite manuscript material in their care.

2 Among the legal problems caused by Scott's anonymity as a novelist, for instance, was the advertising of a spurious fourth series of 'Tales of My Landlord' by 'Jedediah Cleishbotham' in the London press in 1819. While Constable publicly stated that this had no connection with the real author of the series, the publisher William Fearman asserted his or anyone's right to use this fictional author's name-see Edgar Johnson, Sir Walter Scott: The Great Unknown, 2 vols (London: Hamish Hamilton, 1970), I, 685-86.

3 See James Hogg, The Private Memoirs and Confessions of a fustified Sinner, ed. by P. D. Garside (S/SC, 2001), pp. xi, lx.

4 The Collected Letters of James Hogg, ed. by Gillian Hughes and others, 3 vols (S/SC, 2004-08), I, 39 (hereafter referred to as Letters).

5 See, for instance, Hogg's manuscript of 'The Appin Coronach', end-dated 'Mount-Benger|27th July 1828', with a note on an accompanying leaf by Mrs Mary Anne Hughes, 'Given me by Mr Hogg | August 1st 1828 at Abbotsford', in National Library of Scotland (hereafter NLS) Acc. 10,001.

6 The ending of Hogg's Highland Journey of 1802, a small notebook numbered 4, and part of his manuscript for his 1803 Highland Journey in small notebooks numbered 4, 5, and 6 survive in Stirling University Library, MS 
25, Box 1(2). Earlier parts of Hogg's 1802 Highland Journey were published as 'A Journey Through the Highlands of Scotland, in the Months of July and August 1802', in the Scots Magazine between October 1802 and June 1803. $A$ Tour in the Highlands in 1803 was published from Hogg's manuscript by Alexander Gardner of Paisley in 1888. For further details see James Hogg, Highland Journeys, ed. by H. B. de Groot (S/SC, 2010). Evidence of Hogg's transcribing sections of his 1802 Journey for serial publication is provided by his letters to Walter Scott of 10 September [1802] and 1 January [1803], in Letters, I, 20-33.

7 See, for instance, Hogg's letter to Bernard Barton of 5 July [1813], in Letters, I, 150, where Hogg describes the purpose of printing these copies as 'to save myself trouble and give my few secret friends an opportunity of judging fairly'.

8 P. D. Garside, 'An annotated checklist of Hogg's literary manuscripts in the Alexander Turnbull Library, Wellington, New Zealand', The Bibliotheck, 20 (1995), 5-23 (p. 5). This is referred to hereafter as Garside.

9 See Garside, p. 13 for details of Hogg's draft manuscript of 'The First Sermon', no. 31 in this listing.

10 Garside, p. 5.

11 For a description see James Hogg, A Queer Book, ed. by P. D. Garside (S/SC, 1995), pp. 249-50.

12 Hogg to Allan Cunningham, 18 October 1829, in Letters, II, 355.

13 Douglas S. Mack, 'Note on the Genesis of the Texts', in James Hogg, Anecdotes of Scott, ed. by Jill Rubenstein (S/SC, 1999), pp. xxxi-lvi (p. l).

14 For details of Hogg's fair-copy manuscript of 'Strange Letter of a Lunatic' see Garside, p. 7 (no. 2). Hogg's letter to William Blackwood of 28 April 1830 (Letters, II, 381) demonstrates that it had been offered and rejected for publication in Blackwood's Edinburgh Magazine. A rather different version was published in Fraser's Magazine, 2 (December 1830), 526-32.

15 See The Queen's Wake; A Legendary Poem, ed. by Douglas S. Mack (S/SC, 2004), pp. Ixxviii, lxxi.

16 Letters, II, 145, 46. Charles Marshall's reminiscences are to be found in Mary Gray Garden, Memorials of fames Hogg, the Ettrick Shepherd (Paisley and London: Alexander Gardner, n.d.), pp. 296-307 (p. 299).

17 See James Hogg, Anecdotes of Scott, ed. by Jill Rubenstein (S/SC, 1999), pp. 37-75.

18 For details of these manuscripts see Tales of the Wars of Montrose, ed. by Gillian Hughes (S/SC, 1996), pp. 246-52.

19 Douglas S. Mack, 'The Transmission of the Text of Hogg's Brownie of Bodsbeck', The Bibliotheck, 8 nos 1-2 (1976), 7-46 (p. 8).

20 James Hogg, The Brownie of Bodsbeck, ed. by Douglas S. Mack (Edinburgh and London: Scottish Academic Press, 1976), pp. xiii-xiv, xvii.

21 References to Hogg's surviving manuscript in the Fales Manuscript Collection, MSS 1, Boxes 89A-89C, in Fales Library, New York University will generally be given in parentheses in the text, by reference to Hogg's own system of pagination. Deletions are recorded between angle brackets $<$ thus $>$ and insertions between pairs of arrows $\uparrow$ thus $\downarrow$.

22 Hogg to Murray, 4 [July] 1818, in Letters, I, 361. 
23 George Taylor, A Memoir of Robert Surtees, Esq., ed. by James Raine, Surtees Society, 24 (Durham, 1852), p. 157.

24 Similar paper was used, for example, in Hogg's letters to Peter Buchan of 24 June 1818 and to William Blackwood of 15 July 1818-see Letters, I, 360, 363.

25 For Hogg's letter to George Boyd of 27 June 1821 see Letters, II, 94-95.

26 For details of Robert Hogg's career see Gillian Hughes, 'The Ettrick Shepherd's Nephew', Studies in Hogg and his World, 16 (2005), 20-35.

27 Letters, II, 124.

28 Peter Garside, 'The English Novel in the Romantic Era: Consolidation and Dispersal', in The English Novel 1770-1829: A Bibliographical Survey of Prose Fiction Published in the British Isles. Volume II: 1800-1829, ed. by Peter Garside and Rainer Schöwerling (Oxford: OUP, 2000), pp. 15-103 (pp. 49, 52).

29 James Hogg, Anecdotes of Scott, ed. by Jill Rubenstein (S/SC, 1999), pp. 47-48.

30 Hogg to Scott, 16 November 1821, in Letters, II, 123.

31 Hogg to Scott, 10 December 1821, in Letters, II, 129.

32 James Hogg, The Three Perils of Man; or, War, Women, and Witchcraft. A Border Romance, 3 vols (London: Longman, Hurst, Rees, Orme and Brown, 1822), II, 266. Future references to this first edition are given in parentheses.

33 Hogg to Blackwood, 20 August and 7 October 1820, in Letters, II, 43, 46.

34 Hogg's letter to Sir Walter Scott of 26 June 1821 reports that Oliver \& Boyd rejected his Border Romance as "of that cast that must draw down comparisons with the romances of the author of Waverly and manifestly to its disadvantage', while his response to the firm is in a letter to George Boyd of 27 June 1821-see Letters, II, 91-92, 94-95.

35 Graham Tulloch, 'Writing "by advice": Ivanhoe and The Three Perils of Man', Studies in Hogg and his World, 15 (2004), 32-52 (p. 36).

36 Hogg to Blackwood, 3 July 1821, in Letters, II, 97.

37 For texts and full background information to both the 'Translation of an Ancient Chaldee Manuscript' and its proposed successors in the magazine see James Hogg, Contributions to Blackwood's Edinburgh Magazine: Volume 1 1817-1828, ed. by Thomas C. Richardson (S/SC, 2008).

38 For Hogg's 'Eastern Apologues' contributed to the annual Forget Me Not for 1829 see Contributions to Annuals and Gift-Books, ed. by Janette Currie and Gillian Hughes (S/SC, 2006), pp. 48-56. 'A Remarkable Egyptian Story' was published in Fraser's Magazine, 7 (February 1833), 147-58.

39 Hogg had cited the first canto of Byron's Don fuan in 'Love Adventures of Mr George Cochrane'-see Winter Evening Tales, ed. by Ian Duncan (S/SC, 2002), p. 224. (For Byron's reference to Friar Bacon's Brazen Head see Canto I, stanza CCXVII of Don fuan.)

40 For examples, see pp. 154, 192, and 193 in the manuscript.

41 For examples, see pp. 76, 78, 91, 95, 99, and 106 in the manuscript.

42 See p. 159 in the manuscript. Hogg's comments on 'The Dowie Dens of Yarrow' for Scott's Minstrelsy of the Scottish Border in his letter to William Laidlaw of 20 July 1801 refer to 'the Baron of Okwood' (Letters, I, 12). Scott also refers to 'Oakwood' in his note to the ballad-see Minstrelsy of the Scottish Border, second edition, 3 vols (Edinburgh, 1803), III, 73.

43 For a statement of the policy, for example, adopted by the Edinburgh Edition of the Waverley Novels, see David Hewitt's 'General Introduction', in 
Walter Scott, Waverley, ed. by P. D. Garside, EEwN 1 (Edinburgh: Edinburgh University Press, 2007), pp. xi-xvi. Peter Garside argues in the case of Waverley itself that 'there are signs of authorial involvement in both the second and third editions, and suggestions of a more complete overhaul in the case of the sixth' (p. 430).

44 For an account of the financial pressures driving Hogg's publication in the 1820s see Gillian Hughes, James Hogg: A Life (Edinburgh: Edinburgh University Press, 2007), pp. 172-78, 199-200, 218-22.

45 Lines 26 and 30 of page 82 of the manuscript, for instance, both begin with semi-colons, positioned slightly into Hogg's left-hand margin in the space that in other lines he left before the start of the written line.

46 Hogg to Blackwood, 16 November 1819, in Letters, I, 423. 